\title{
EFFECT OF BLOOD SERUM FROM PATIENTS WITH MYASTHENIA GRAVIS ON THE SYNTHESIS OF ACETYLCHOLINE IN VITRO ${ }^{1}$
}

\author{
By CLARA TORDA AND HAROLD G. WOLFF \\ (From the New York Hospital and the Departments of Medicine (Neurology) and Psychiatry, Cornell \\ University Medical College, New York City)
}

(Received for publication August 26, 1943)

\section{INTRODUCTION}

Walker's observation (1) that neostigmine, ${ }^{2}$ a choline esterase inhibitor, benefited patients with myasthenia gravis, suggested that the acetylcholine metabolism was disturbed in such patients. Assuming that this conception has validity, the dominant possibilities concerning myasthenia gravis are: $(a)$ excessive destruction of acetylcholine, due to unusually large amounts of choline esterase; $(b)$ defects in the ability of muscle to respond to acetylcholine; and (c) defects in the synthesis or release of acetylcholine.

The choline esterase level of the serum is not unusual in patients with myasthenia gravis, as was shown by Milhorat (2). Lanari (3), and Harvey and collaborators (4 to 6) demonstrated that the skeletal muscle of patients with myasthenia gravis is capable of reacting to acetylcholine and, indeed, is especially sensitive. Harvey and Lilienthal (5) suggested that this increased sensitivity represented a change in muscle threshold because of its exposure to diminishing amounts of acetylcholine.

The most plausible hypothesis is that there exists a fundamental defect in the synthesis of acetylcholine in patients with myasthenia gravis. Dr. Otto Loewi suggested that such synthesis be investigated. ${ }^{3}$

\section{MATERIAL}

The sera of 5 healthy subjects and 59 patients with diseases other than myasthenia gravis were used as controls. Summaries of the clinical state of 9 patients with myasthenia gravis are presented in Table I. In the ninth patient $(\mathrm{N})$, the diagnosis of myasthenia gravis, although probable, was difficult to establish.

1 This study was aided by a grant from the Josiah Macy, Jr. Foundation.

2 Prostigmine (Hoffmann-La Roche).

3 We are immeasurably indebted to Dr. Loewi for his enthusiastic interest in the development of the problem, and for his valuable advice on technic.

\section{EFFECT OF HUMAN SERUM ON THE SYNTHESIS} OF ACETYLCHOLINE

Principles and outline of method. The method of Quastel, Tennenbaum, and Wheatley (7) was modified for use in this demonstration. The bases of the method utilized are: (a) uniform samples of nerve tissue under standard environmental conditions will synthesize acetylcholine at a fixed rate; $(b)$ the amount of acetylcholine thus synthesized may be biologically assayed by measuring its effect in inducing contraction in a properly sensitized muscle. The relative ability of 2 media to influence the synthesis of acetylcholine can thus be measured. In this series of experiments, the nerve tissue was frog brain. The indicator of acetylcholine content was the rectus abdominis muscle of the frog. The effect on acetylcholine synthesis of sera from patients with myasthenia gravis was compared with the effect on acetylcholine synthesis of control sera.

Collection and preparation of samples. The frog brain medium was prepared by mincing with scissors the freshly dissected whole brains of 10 to 25 frogs. Hundred mgm. samples were rapidly weighed from this homogeneous stock.

Blood samples were usually collected before breakfast. All blood samples were immediately defibrinated by shak- . ing with glass perles for 5 minutes, and then promptly centrifuged. The supernatant serum was used for analysis. Only clear yellow sera were used and specimens with hemolysis were discarded. From each individual serum, specimens in triplicate were prepared as follows: 1 cc. of serum was mixed with $100 \mathrm{mgm}$. of frog brain, 1 cc. of Ringer's solution at pH 7.4, 1 cc. of Ringer's solution containing $3 \mathrm{mgm}$. of physostigmine salicylate, and $0.3 \mathrm{cc}$. of Ringer's solution containing $4.8 \mathrm{mgm}$. of glucose.

The Ringer's solution used in preparing mixtures for incubation was of the mammalian type and each $100 \mathrm{cc}$. contained 0.9 gram of $\mathrm{NaCl}, 0.4$ gram of $\mathrm{KCl}, 0.011$ gram of $\mathrm{CaCl}_{2}$, and phosphate buffer $(\mathrm{M} / 100)$ to give a $\mathrm{pH}$ value of 7.4. (The final concentration of the phosphorus was 0.03 gram per $100 \mathrm{cc}$. of Ringer's solution.) The $\mathrm{pH}$ of all mixtures was corrected to 7.4 , the $\mathrm{pH}$ of blood, before incubation because the amount of acetylcholine synthesized depends on the $\mathrm{pH}$.

Incubation. The mixtures were placed in vessels mounted on a shaking machine and shaken and incubated for $\mathbf{4}$ hours in a water bath. At short intervals through-

4 The results were more uniform and small differences in the synthesis in the presence of serum were more readily demonstrable with frog brain than with mammalian brain. 
TABLE I

Short summary of the clinical state of 8 patients with myasthenia gravis

\begin{tabular}{|c|c|c|c|c|c|c|c|c|c|c|}
\hline \multirow[b]{2}{*}{ Name } & \multirow[b]{2}{*}{ Sex } & \multirow[b]{2}{*}{ Age } & \multirow{2}{*}{$\begin{array}{l}\text { Severity } \\
\text { of } \\
\text { disease }\end{array}$} & \multirow[b]{2}{*}{$\begin{array}{l}\text { Dura- } \\
\text { tion }\end{array}$} & \multirow[b]{2}{*}{$\begin{array}{l}\text { Thymec- } \\
\text { tomy }\end{array}$} & \multirow{2}{*}{$\begin{array}{l}\text { X-ray } \\
\text { treat- } \\
\text { ment }\end{array}$} & \multirow[b]{2}{*}{ Symptomatology } & \multicolumn{3}{|c|}{ 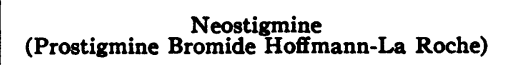 } \\
\hline & & & & & & & & $\begin{array}{l}\text { Dose } \\
\text { before } \\
\text { thymec- } \\
\text { tomy }\end{array}$ & Dose & $\begin{array}{l}\text { Achievement after } \\
\text { medication }\end{array}$ \\
\hline $\mathbf{H}$ & $\mathbf{F}$ & $\begin{array}{c}\text { years } \\
43\end{array}$ & $5+$ & $\begin{array}{l}\text { years } \\
15\end{array}$ & Yes & Yes & $\begin{array}{l}\text { Bedridden, severe lid ptosis, di- } \\
\text { plopia, constant difficulty in } \\
\text { chewing and swallowing, very }\end{array}$ & $\begin{array}{c}\text { mgm. } \\
\text { per day } \\
225\end{array}$ & $\begin{array}{c}\text { mgm. } \\
\text { per day } \\
120 \text { to } 180\end{array}$ & $\begin{array}{l}\text { Chews food, turns } \\
\text { in bed, sits on } \\
\text { chair }\end{array}$ \\
\hline G & F & 39 & $4+$ & 3 & No & Yes & $\begin{array}{l}\text { severe muscular fatiguability } \\
\text { Almost bedridden, severe lid } \\
\text { ptosis, diplopia, difficulty in } \\
\text { chewing and swallowing, se- } \\
\text { vere muscular fatiguability }\end{array}$ & & 135 & $\begin{array}{l}\text { Sits in chair for a } \\
\text { greater number } \\
\text { of hours, can } \\
\text { walk a few steps }\end{array}$ \\
\hline $\mathbf{R}$ & $\mathbf{F}$ & 23 & $3+$ & 9 & No & No & $\begin{array}{l}\text { Moderate lid ptosis, occasional } \\
\text { diplopia, occasional dificulty } \\
\text { in chewing, moderate muscu- } \\
\text { lar fatiguability }\end{array}$ & & 90 & Walks 1 to 2 blocks \\
\hline $\mathrm{Sa}$ & F & 32 & $3+$ & 7 & No & No & $\begin{array}{l}\text { Moderate lid ptosis, occasional } \\
\text { diplopia, occasional difficulty } \\
\text { in chewing, moderate muscu- } \\
\text { lar fatiguability }\end{array}$ & & 90 to 150 & Housework \\
\hline $\mathbf{S}$ & $\mathbf{M}$ & 22 & $2+$ & 2 & Yes & No & $\begin{array}{l}\text { Slight lid ptosis, rare diplopia, } \\
\text { moderate muscular fatigua- } \\
\text { bility }\end{array}$ & 120 & 15 to 45 & $\begin{array}{l}\text { Works as an in- } \\
\text { spector of ma- } \\
\text { chinery }\end{array}$ \\
\hline V & $\mathbf{F}$ & 20 & $2+$ & $5 \frac{1}{2}$ & No & No & $\begin{array}{l}\text { Slight lid ptosis, rare diplopia, } \\
\text { occasional difficulty in chew- } \\
\text { ing, mild muscular fatigua- }\end{array}$ & & 45 to 75 & $\begin{array}{l}\text { Walks, goes to } \\
\text { parties }\end{array}$ \\
\hline $\mathbf{P}$ & $\mathbf{M}$ & 36 & $2+$ & 2 & No & No & Dilfity & & 75 & $\begin{array}{l}\text { Walks, but unable } \\
\text { to work }\end{array}$ \\
\hline $\mathbf{M}$ & $\mathbf{F}$ & 27 & $2+$ & 6 & No & No & $\begin{array}{l}\text { Slight lid ptosis, rare diplopia, } \\
\text { occasional difficulty in chew- } \\
\text { ing, mild muscular fatigua- } \\
\text { bility }\end{array}$ & & 15 to 45 & $\begin{array}{l}\text { Works as a cashier } \\
\text { (against advice } \\
\text { takes as high as } \\
135 \mathrm{mgm} \text {. for al- } \\
\text { most normal } \\
\text { function) }\end{array}$ \\
\hline $\mathrm{N}^{*}$ & F & 47 & $1+$ & 12 & No & No & Mild muscular fatiguability & & & Housework \\
\hline
\end{tabular}

* Doubtful.

out the incubation, the gas above the mixtures was replaced by oxygen. Incubations were made at $23^{\circ} \mathrm{C}$. and at $38^{\circ} \mathrm{C}$.

After 4 hours of incubation, $1.2 \mathrm{cc}$. of distilled water were added to the samples to convert the osmotic pressure to that of frog Ringer's solution and the volume was made up to $10 \mathrm{cc}$. with frog Ringer's solution. (The Ringer's solution of the frog type contained 0.67 gram of $\mathrm{NaCl}, 0.02$ gram of $\mathrm{KCl}$, and 0.015 gram of $\mathrm{CaCl}_{2}$ in $100 \mathrm{cc}$.) The $\mathrm{pH}$ was corrected to 6.8 , and kept constant throughout all following steps of the analysis. (Both the magnitude of the contraction of the rectus abdominis muscle and the stability of the acetylcholine before and during boiling are modified by variations in the $\mathrm{pH}$.)

The mixtures were then centrifuged. After centrifuging, the acetylcholine content of the supernatant fluid was ascertained by measuring the magnitude of contractions of the sensitized rectus abdominis muscle of the frog.

Preparation of the rectus abdominis muscle. The rectus abdominis muscle of the frog was excised, immersed in
Ringer's solution, and kept in an ice-box $\left(2^{\circ} \mathrm{C}\right.$.) for 2 hours to promote uniform responses of the muscle. The muscle was then suspended in a muscle chamber of $10 \mathrm{cc}$. capacity (method of Riesser (8) and Chang and Gaddum (9)), and sensitized by immersion for half an hour in Ringer's solution (at room temperature) containing $2 \mathrm{mgm}$. physostigmine salicylate per $100 \mathrm{cc}$. Thereupon, the physostigmine solution was replaced for 2 minutes by a solution containing $10 \mu \mathrm{gm}$. acetylcholine per $100 \mathrm{cc}$. The magnitude of contraction was registered by an isotonic lever on a kymograph. The muscle was then immersed for 5 minutes in Ringer's solution, followed by 5 minutes in a solution of physostigmine, and then again by immersion in the above acetylcholine solution. The procedure was repeated until 3 successive exposures to the solution of acetylcholine gave similar responses. (Between all subsequent immersions in any contraction inducing solution, the muscle was washed for 5 minutes with Ringer's solution and for 5 minutes with the Ringer's solution containing physostigmine.) The writing lever of the kymograph was so 
weighted as to bring the contraction within the submaximal range where the muscle is sensitive to small changes in the concentration of acetylcholine.

These preliminary steps completed, the muscle was immersed for 2 minutes in one of the unknown solutions. Then, after measuring the contraction induced by the unknown solution, the muscle was immersed in sequence in a series of standard acetylcholine solutions, of concentrations covering the range of the unknown solutions. The acetylcholine content was thus ascertained for each unknown solution.

Assay of acetylcholine synthesis. The acetylcholine content of the mixtures, enumerated in Table II, was assayed.

It has been suggested $(10,11)$ that boiling brain tissue makes available the intracellular bound acetylcholine. Therefore these assay procedures were repeated after boiling. The residue of brain previously removed by centrifugation was suspended in the diluted supernatant fluid used in the above described procedure, and the whole boiled for 2 minutes at $\mathrm{pH}$ 6.8. It was then re-centrifuged and the supernantant fluid assayed for acetylcholine content by measuring the magnitude of contraction of the rectus abdominis muscle of frog as described above.

The stability of the muscle was tested before and after the assay of each unknown solution by immersion in standard acetylcholine solutions.

The acetylcholine content of each mixture was assayed on 2 to 12 different rectus abdominis muscle preparations. Thus, calculations on acetylcholine synthesis in each individual serum specimen were based on results obtained from at least 5 muscles.

Demonstration that the contractions induced by the mixtures are due to acetylcholine. To be certain that the contraction was induced by acetylcholine contained in the unknown solution and not by other substances, the muscles were immersed in the same unknown solution before and after being sensitized by immersion in physostigmine. Since only acetylcholine effects are significantly modified by physostigmine, it was inferred that any contraction that was augmented by physostigmine was due to acetylcholine.

Test for the occurrence of a substance that interferes with the action of acetylcholine on the rectus abdominis muscle. There is a possibility that during the 4 hours of incubation, other substances were produced in unequal quantities in the mixtures containing frog brain-control serum and frog brain-serum from patients with myasthenia gravis. Some of these substances might prevent acetylcholine from inducing contraction of the rectus abdominis muscle. If so, it is conceivable that the magnitude of the contraction of the rectus abdominis muscle on immersion in the incubated mixtures is the result of 2 effects: (a) the contraction inducing action of acetylcholine, and $(b)$ the effect of an agent which prevents the acetylcholine from acting on the muscle. To investigate this possibility, we incubated for 4 hours mixtures containing frog brain, glucose, and control serum, or serum from a patient $(\mathrm{H})$ with myasthenia gravis, but not containing physostigmine. In these mixtures, the acetylcholine synthesized was destroyed by the choline esterase present. Therefore, the incubated mixtures did not induce contraction of the rectus abdominis muscle. After incubation, the mixtures were diluted to $10 \mathrm{cc}$., as described above, and rectus abdominis muscles were immersed in these solutions for $\mathbf{3 0}$ minutes and afterwards immersed for 2 minutes in solutions of acetylcholine of known concentrations. It was found that neither mixture ( $(a)$ frog brain-control serum and $(b)$ frog brainserum from patient $\mathrm{H}$ with myasthenia gravis) modified the expected effect of acetylcholine. Therefore, it may be assumed that in such incubated mixtures, no substance was developed in sufficient concentration to prevent acetylcholine from acting on the rectus abdominis muscle of the frog.

Calculation of synthesis of acetylcholine. The acetylcholine synthesis within the incubated mixtures was calculated by subtracting from the acetylcholine content of the incubated mixtures the acetylcholine content of identical non-incubated mixtures. Comparisons were made between the acetylcholine synthesis resulting from the mixtures containing control serum, and those containing the serum from patients with myasthenia gravis. ${ }^{5}$

6 The method employed for the assay of acetylcholine, as with all bioassays of this type, gave considerable variation in the results obtained in individual experiments. However, a sufficient number of experiments were performed in each group to assure the significance of the difference reported between the effect of control serum and serum from patients with myasthenia gravis.

TABLE II

Assay of acetylcholine synthesis

\begin{tabular}{|c|c|c|c|c|c|c|c|}
\hline \multirow{2}{*}{ State } & \multirow{2}{*}{ Frog brain } & \multirow{2}{*}{$\begin{array}{l}\text { Ringer's } \\
\text { solution }\end{array}$} & \multirow{2}{*}{ Serum } & \multicolumn{2}{|c|}{$\begin{array}{c}\text { Physostigmine } \\
\text { salicylate }\end{array}$} & \multicolumn{2}{|r|}{ Glucose } \\
\hline & & & & & $\underset{\text { concentration }}{\text { Final }}$ & & $\underset{\text { concentration }}{\text { Final }}$ \\
\hline $\begin{array}{l}\text { IA. non-incubated } \\
\text { IB. non-incubated }\end{array}$ & $\begin{array}{l}m g m . \\
100 \\
100\end{array}$ & $\begin{array}{l}c c . \\
3.3 \\
2.3\end{array}$ & $\begin{array}{l}c c . \\
0 \\
1\end{array}$ & $\begin{array}{c}m g m . \\
3 \\
3\end{array}$ & $\begin{array}{c}\text { grams per } 100 \mathrm{cc} . \\
0.09 \\
0.09\end{array}$ & $\begin{array}{c}m g m . \\
4.8 \\
4.8\end{array}$ & $\begin{array}{c}\text { grams per } 100 \mathrm{cc} . \\
0.15 \\
0.15\end{array}$ \\
\hline $\begin{array}{l}\text { IIA. incubated } \\
\text { IIB. incubated } \\
\text { IIC. incubated }\end{array}$ & $\begin{array}{l}100 \\
100 \\
100\end{array}$ & $\begin{array}{l}3.3 \\
2.3 \\
2.3\end{array}$ & $\begin{array}{l}0 \\
1 \text { (control serum) } \\
1 \text { (myasthenia gravis) }\end{array}$ & $\begin{array}{l}3 \\
3 \\
3\end{array}$ & $\begin{array}{l}0.09 \\
0.09 \\
0.09\end{array}$ & $\begin{array}{l}4.8 \\
4.8 \\
4.8\end{array}$ & $\begin{array}{l}0.15 \\
0.15 \\
0.15\end{array}$ \\
\hline
\end{tabular}




\section{RESULTS}

Series 1. A comparison of the effect of control serum and serum from patients with myasthenia gravis on acetylcholine synthesis

\section{Fresh non-incubated mixtures}

A. Frog brain-Ringer's solution. The acetylcholine content of mixtures of frog brain-Ringer's solution, as assayed before boiling, averaged 0.39 $\mu \mathrm{gm}$. and, as assayed after boiling, averaged $\mathbf{0 . 8 0}$ $\mu \mathrm{gm}$. per $100 \mathrm{mgm}$. frog brain (Table III).

B. Frog brain-serum. Mixtures containing frog brain-control serum and frog brain-serum from patients with myasthenia gravis gave less constant results but, when averaged, the acetylcholine content was approximately the same as that of frog brain-Ringer's solution mixtures (Table III).

\section{Incubated mixtures}

A. Frog brain-Ringer's solution. The amount of acetylcholine synthesized at $23^{\circ} \mathrm{C}$. by a mixture of frog brain-Ringer's solution, as assayed before boiling, averaged $0.70 \mu \mathrm{gm}$. and, as assayed after boiling, averaged $1.50 \mu \mathrm{gm}$. acetylcholine per $100 \mathrm{mgm}$. of frog brain. The amount of acetylcholine synthesized at $38^{\circ} \mathrm{C}$., as assayed before boiling, averaged $0.41 \mu \mathrm{gm}$. acetylcholine, and, as assayed after boiling, averaged $1.02 \mu \mathrm{gm}$. acetylcholine per $100 \mathrm{mgm}$. of frog brain (Tables IV and V).

B. Frog brain-control serum. Five healthy persons and 59 patients with diseases other than myasthenia gravis served as controls. The patients had the following diseases: multiple sclerosis, brain tumor, cerebral accident, paresis, encephalitis, peripheral neuritis, ruptured disk, arterial hypertension, subacute bacterial endocarditis, secondary anemia, uremia, asthma, diabetes, lead poisoning, "gastro-enteritis," hyperthyroidism, myalgia, and undiagnosed muscular weakness. One hundred and two separate blood samples were collected and incubated in triplicate. The amount of acetylcholine synthesized at $23^{\circ} \mathrm{C}$. by a mixture of frog brain-control serum, as assayed before boiling, averaged 1.16 $\mu \mathrm{gm}$. acetylcholine, and as assayed after boiling, averaged $1.73 \mu \mathrm{gm}$. acetylcholine per $100 \mathrm{mgm}$. of tissue. The amount of acetylcholine synthesized at $38^{\circ} \mathrm{C}$., as assayed before boiling, averaged $1.45 \mu \mathrm{gm}$. acetylcholine, and as assayed after boiling, averaged $2.08 \mu \mathrm{gm}$. acetylcholine per $100 \mathrm{mgm}$. of tissue. The amount of acetylcholine synthesized in the presence of serum of healthy subjects and of the patients with diseases

TABLE III

Acetylcholine content of freshly prepared non-incubated mixtures expressed in $\mu g m$. per 100 mgm. of tissue

\begin{tabular}{|c|c|c|c|c|c|c|c|c|}
\hline \multirow{3}{*}{$\begin{array}{l}\text { Mixtures containing } \\
\text { frog brain and }\end{array}$} & \multicolumn{4}{|c|}{ Assays of non-boiled mixtures } & \multicolumn{4}{|c|}{ Assays of boiled mixtures } \\
\hline & \multirow{2}{*}{$\begin{array}{l}\text { No. of } \\
\text { separate } \\
\text { mixtures }\end{array}$} & \multirow{2}{*}{$\begin{array}{c}\text { No. of } \\
\text { rectus } \\
\text { abdominis } \\
\text { muscles }\end{array}$} & \multicolumn{2}{|c|}{ Acetylcholine content } & \multirow{2}{*}{$\begin{array}{l}\text { No. of } \\
\text { separate } \\
\text { mixtures }\end{array}$} & \multirow{2}{*}{$\begin{array}{c}\text { No. of } \\
\text { rectus } \\
\text { abdominis } \\
\text { muscles }\end{array}$} & \multicolumn{2}{|c|}{ Acetylcholine content } \\
\hline & & & Mean & S. $\mathbf{E}$. & & & Mean & S. E. \\
\hline $\begin{array}{l}\text { Ringer's solution } \\
\text { Serum }\end{array}$ & $\begin{array}{l}40 \\
40\end{array}$ & $\begin{array}{l}157 \\
157\end{array}$ & $\begin{array}{l}0.39 \\
0.38\end{array}$ & $\begin{array}{l} \pm 0.011 \\
\pm 0.029\end{array}$ & $\begin{array}{l}20 \\
20\end{array}$ & $\begin{array}{l}59 \\
59\end{array}$ & $\begin{array}{l}0.80 \\
0.82\end{array}$ & $\begin{array}{l} \pm 0.022 \\
\pm 0.035\end{array}$ \\
\hline
\end{tabular}

TABLE IV

Acetylcholine synthesis during 4 hours' incubation in mixtures containing frog brain and Ringer's solution expressed in $\mu \mathrm{gm}$. per $100 \mathrm{mgm}$. of frog brain

\begin{tabular}{|c|c|c|c|c|c|c|c|c|c|c|c|c|c|c|c|}
\hline \multicolumn{4}{|c|}{$\begin{array}{l}\text { Assays of non-boiled mixtures } \\
\left(38^{\circ} \mathrm{C} .\right)\end{array}$} & \multicolumn{4}{|c|}{$\begin{array}{l}\text { Assays of boiled mixtures } \\
\left(38^{\circ} \mathrm{C} .\right)\end{array}$} & \multicolumn{4}{|c|}{$\begin{array}{c}\text { Assays of non-boiled mixtures } \\
\left(23^{\circ} \mathrm{C} .\right)\end{array}$} & \multicolumn{4}{|c|}{$\begin{array}{l}\text { Assays of boiled mixtures } \\
\left(23^{\circ} \mathrm{C} .\right)\end{array}$} \\
\hline \multirow{2}{*}{$\begin{array}{l}\text { No. of } \\
\text { incu- } \\
\text { bated } \\
\text { mix- } \\
\text { tures }\end{array}$} & \multirow{2}{*}{$\begin{array}{l}\text { No. of } \\
\text { rectus } \\
\text { abdo- } \\
\text { minis } \\
\text { muscles }\end{array}$} & \multicolumn{2}{|c|}{$\begin{array}{l}\text { Acetylcholine } \\
\text { synthesis }\end{array}$} & \multirow{2}{*}{$\begin{array}{l}\text { No. of } \\
\text { incu- } \\
\text { bated } \\
\text { mix- } \\
\text { tures }\end{array}$} & \multirow{2}{*}{$\begin{array}{c}\text { No. of } \\
\text { rectus } \\
\text { abdo- } \\
\text { minis } \\
\text { muscles }\end{array}$} & \multicolumn{2}{|c|}{$\begin{array}{l}\text { Acetylcholine } \\
\text { synthesis }\end{array}$} & \multirow{2}{*}{$\begin{array}{l}\text { No. of } \\
\text { incu- } \\
\text { bated } \\
\text { mix- } \\
\text { tures }\end{array}$} & \multirow{2}{*}{$\begin{array}{l}\text { No. of } \\
\text { rectus } \\
\text { abdo- } \\
\text { minis } \\
\text { muscles }\end{array}$} & \multicolumn{2}{|c|}{$\begin{array}{l}\text { Acetylcholine } \\
\text { synthesis }\end{array}$} & \multirow{2}{*}{$\begin{array}{l}\text { No. of } \\
\text { incu- } \\
\text { bated } \\
\text { mix- } \\
\text { tures }\end{array}$} & \multirow{2}{*}{$\begin{array}{l}\text { No. of } \\
\text { rectus } \\
\text { abdo- } \\
\text { minis } \\
\text { muscles }\end{array}$} & \multicolumn{2}{|c|}{$\begin{array}{l}\text { Acetylcholine } \\
\text { synthesis }\end{array}$} \\
\hline & & Mean & S.E. & & & Mean & S.E. & & & Mean & S.E. & & & Mean & S.E. \\
\hline 22 & 60 & $\begin{array}{l}\mu g m . \\
0.41\end{array}$ & \pm 0.013 & 28 & 55 & $\begin{array}{l}\mu g m . \\
1.02\end{array}$ & \pm 0.033 & 9 & 14 & $\begin{array}{l}\mu g m . \\
0.70\end{array}$ & \pm 0.023 & 9 & 14 & $\begin{array}{l}\mu g m . \\
1.50\end{array}$ & \pm 0.044 \\
\hline
\end{tabular}


TABLE V

Comparison of the amounts of acetylcholine synthesized in the mixtures containing: 1. Frog brain-Ringer's solution; 2. Frog brain-control serum; and 3. Frog brain-serum from patients with myasthenia gravis

Average of the acetylcholine synthesized during 4 hours of incubation expressed in $\mu \mathrm{gm}$. per $100 \mathrm{mgm}$. of frog brain

\begin{tabular}{|c|c|c|c|c|}
\hline \multirow{2}{*}{$\begin{array}{l}\text { Mixtures containing frog brain, } \\
\text { glucose, physostigmine, and }\end{array}$} & \multicolumn{4}{|c|}{ Assays of mixtures } \\
\hline & $\begin{array}{l}\text { Non- } \\
\text { boiled } \\
23^{\circ} \mathrm{C} .\end{array}$ & $\begin{array}{l}\text { Boiled } \\
2^{\circ} \mathrm{C} .\end{array}$ & $\begin{array}{l}\text { Non- } \\
\text { boiled } \\
38^{\circ} \mathrm{C} \text {. }\end{array}$ & $\begin{array}{l}\text { Boiled } \\
38^{\circ} \mathrm{C} \text {. }\end{array}$ \\
\hline $\begin{array}{l}\text { Ringer's solution } \\
\text { Control serum }\end{array}$ & $\begin{array}{l}0.70 \\
1.16\end{array}$ & $\begin{array}{l}1.50 \\
1.73\end{array}$ & $\begin{array}{l}0.41 \\
1.45\end{array}$ & $\begin{array}{l}1.02 \\
2.08\end{array}$ \\
\hline $\begin{array}{l}\text { Myasthenia gravis serum } \\
\mathbf{H}++++^{*} \\
\mathrm{G}++++ \\
\mathrm{R}+++ \\
\mathbf{S a}+++ \\
\mathbf{S}++ \\
\mathbf{M}++ \\
\mathbf{P}++ \\
\mathrm{V}++ \\
\mathbf{N}+\text { ? }\end{array}$ & $\begin{array}{l}0.47 \\
0.59\end{array}$ & $\begin{array}{l}0.75 \\
0.92\end{array}$ & $\begin{array}{l}0.53 \\
0.65 \\
0.79 \\
0.82 \\
0.88 \\
0.91 \\
0.91 \\
0.92 \\
1.17\end{array}$ & $\begin{array}{l}0.90 \\
1.11 \\
1.16 \\
\\
1.29 \\
1.30 \\
1.69\end{array}$ \\
\hline
\end{tabular}

* Most seriously ill patient: +++++ ; least seriously ill patient: + .

other than myasthenia gravis deviated from the average not more than \pm 15 per cent and usually less than \pm 10 per cent.

C. Frog brain-serum from patients with myasthenia gravis. The synthesis of acetylcholine in the mixtures of frog brain and serum from seriously incapacitated patients with myasthenia gravis was less than half that found in mixtures of frog brain-control serum. The amount of acetylcholine synthesized at $23^{\circ} \mathrm{C}$. by mixtures of frog brain and serum from patient $\mathrm{H}$ with severe myasthenia gravis, as assayed before boiling, averaged $0.47 \mu \mathrm{gm}$. acetylcholine, and, as assayed after boiling, averaged $0.75 \mu \mathrm{gm}$. acetylcholine per $100 \mathrm{mgm}$. of tissue. The amount of acetylcholine synthesized at $38^{\circ} \mathrm{C}$., as assayed before boiling, averaged $0.53 \mu \mathrm{gm}$. acetylcholine, and, as assayed after boiling, averaged $0.90 \mu \mathrm{gm}$. acetylcholine per $100 \mathrm{mgm}$. of tissue (Tables $\mathrm{V}$ and VI).

The most serious decrease in the synthesis of acetylcholine was noted in the mixtures containing serum from the patients most seriously ill with myasthenia gravis. The samples from the patient with the least impairment $(\mathrm{N})$, constituting a borderline myasthenic state, presented a defect in synthesis barely below the level of some of the controls (Tables V and VI). ${ }^{6}$

- While this paper was in press, results similar to those of case $S$ were obtained using serum of 3 additional and comparable patients with myasthenia gravis.

TABLE VI

Acetylcholine synthesized during 4 hours' incubation in mixtures containing frog brain and serum from patients with myasthenia gravis expressed in $\mu \mathrm{gm}$. per $100 \mathrm{mgm}$. of tissue

\begin{tabular}{|c|c|c|c|c|c|c|c|c|c|c|c|c|c|c|c|c|}
\hline \multirow{3}{*}{ Subject } & \multicolumn{8}{|c|}{ Assays of non-boiled mixtures $\left(38^{\circ} \mathrm{C}.\right)$} & \multicolumn{8}{|c|}{ Assays of boiled mixtures $\left(38^{\circ} \mathrm{C}.\right)$} \\
\hline & \multirow{2}{*}{$\begin{array}{l}\text { No. of } \\
\text { sepa- } \\
\text { rate } \\
\text { blood } \\
\text { samples }\end{array}$} & \multirow[b]{2}{*}{$\begin{array}{l}\text { No. of } \\
\text { incu- } \\
\text { bated } \\
\text { mix- } \\
\text { tures }\end{array}$} & \multirow[b]{2}{*}{$\begin{array}{l}\text { No. of } \\
\text { rectus } \\
\text { abdom- } \\
\text { inis } \\
\text { muscles }\end{array}$} & \multicolumn{5}{|c|}{ Acotylcholine synthesis } & \multirow[b]{2}{*}{$\begin{array}{l}\text { No. of } \\
\text { sepa- } \\
\text { rate } \\
\text { blood } \\
\text { samples }\end{array}$} & \multirow[b]{2}{*}{$\begin{array}{l}\text { No. of } \\
\text { incu- } \\
\text { bated } \\
\text { mix- } \\
\text { tures }\end{array}$} & \multirow[b]{2}{*}{$\begin{array}{c}\text { No. of } \\
\text { rectus } \\
\text { abdom- } \\
\text { inis } \\
\text { muscles }\end{array}$} & \multicolumn{5}{|c|}{ Acetylcholine synthesis } \\
\hline & & & & $\begin{array}{l}\text { Minimum- } \\
\text { maximum }\end{array}$ & Mean & S.E. & $\begin{array}{c}\text { Deviation } \\
\text { in per- } \\
\text { centage } \\
\text { of } \\
\text { average }\end{array}$ & $\begin{array}{c}\text { Percent- } \\
\text { age of } \\
\text { control } \\
\dagger\end{array}$ & & & & $\begin{array}{l}\text { Minimum- } \\
\text { maximum }\end{array}$ & Mean & S.E. & $\begin{array}{l}\text { Devia- } \\
\text { tion, per- } \\
\text { centage } \\
\text { of } \\
\text { average }\end{array}$ & $\begin{array}{l}\text { Percent- } \\
\text { age of } \\
\text { control }\end{array}$ \\
\hline \multirow[t]{2}{*}{$\begin{array}{l}\mathrm{H}++ \\
\mathrm{G}++ \\
\mathrm{R}++ \\
\mathrm{S}++ \\
\mathrm{S}++ \\
\mathrm{M}++ \\
\mathrm{P}++ \\
\mathrm{V}++ \\
\mathrm{N}+\mathrm{+}\end{array}$} & $\begin{array}{r}11 \\
4 \\
4 \\
3 \\
4 \\
1 \\
1 \\
1 \\
4\end{array}$ & $\begin{array}{r}32 \\
12 \\
12 \\
9 \\
12 \\
3 \\
3 \\
2 \\
12\end{array}$ & $\begin{array}{r}85 \\
27 \\
46 \\
20 \\
40 \\
6 \\
6 \\
6 \\
21\end{array}$ & $\begin{array}{c}\mu g m . \\
0.42 \text { to } 0.61 \\
0.60 \text { to } 0.75 \\
0.70 \text { to } 0.90 \\
0.76 \text { to } 0.88 \\
0.82 \text { to } 0.94 \\
0.87 \text { to } 0.95 \\
0.86 \text { to } 0.94 \\
0.88 \text { to } 0.95 \\
1.07 \text { to } 1.23\end{array}$ & $\begin{array}{l}\mu g m . \\
0.53 \\
0.65 \\
0.79 \\
0.82 \\
0.88 \\
0.91 \\
0.91 \\
0.92 \\
1.17\end{array}$ & $\begin{array}{l} \pm 0.024 \\
\pm 0.010 \\
\pm 0.012 \\
\pm 0013 \\
\pm 0.010 \\
\pm 0.014 \\
\pm 0.018 \\
\pm 0.016 \\
\pm 0.015\end{array}$ & $\begin{array}{r}-20 /+15 \\
-8 /+15 \\
-11 /+14 \\
-7 /+7 \\
-7 /+7 \\
-5 /+4 \\
-6 /+3 \\
-4 /+3 \\
-9 /+5\end{array}$ & $\begin{array}{l}36.6^{*} \\
44.9 \\
54.6 \\
56.6 \\
60.8 \\
62.9 \\
62.9 \\
63.6 \\
80.8\end{array}$ & $\begin{array}{l}1 \\
4 \\
3 \\
\\
\\
1\end{array}$ & $\begin{array}{r}2 \\
12 \\
9 \\
\\
3 \\
2 \\
12\end{array}$ & $\begin{array}{r}6 \\
24 \\
20 \\
\\
\\
6 \\
6 \\
24\end{array}$ & $\begin{array}{c}\mu g m . \\
0.86 \text { to } 0.85 \\
1.02 \text { to } 1.19 \\
1.08 \text { to } 1.23 \\
1.20 \text { to } 1.36 \\
1.22 \text { to } 1.34 \\
1.49 \text { to } 1.80\end{array}$ & $\begin{array}{l}\mu g m . \\
0.90 \\
1.11 \\
1.16 \\
\\
1.29 \\
1.30 \\
1.69\end{array}$ & $\begin{array}{l} \pm 0.017 \\
\pm 0.014 \\
\pm 0.016 \\
\\
\pm 0.028 \\
\pm 0.026 \\
\pm 0.031\end{array}$ & $\begin{array}{r}-5 /+5 \\
-8 /+7 \\
-7 /+6 \\
\\
-7 /+5 \\
-6 /+3 \\
-12 /+6\end{array}$ & $\begin{array}{l}43.2 * * \\
53.4 \\
55.7 \\
\\
62.1 \\
62.5 \\
81.3\end{array}$ \\
\hline & \multicolumn{8}{|c|}{$\left(23^{\circ} \mathrm{C}.\right)$} & \multicolumn{8}{|c|}{$\left(23^{\circ} \mathrm{C}.\right)$} \\
\hline $\begin{array}{l}\mathbf{H}+++ \\
\mathbf{R}+++ \\
\mathbf{V}++ \\
\mathbf{N}+?\end{array}$ & $\begin{array}{l}1 \\
4 \\
1 \\
2\end{array}$ & $\begin{array}{r}2 \\
12 \\
2 \\
8\end{array}$ & $\begin{array}{r}6 \\
30 \\
6 \\
20\end{array}$ & $\begin{array}{l}0.42 \text { to } 0.52 \\
0.54 \text { to } 0.64 \\
0.69 \text { to } 0.80 \\
0.87 \text { to } 0.97\end{array}$ & $\begin{array}{l}0.47 \\
0.59 \\
0.75 \\
0.93\end{array}$ & $\begin{array}{l} \pm 0.022 \\
\pm 0.010 \\
\pm 0.024 \\
\pm 0.011\end{array}$ & $\begin{array}{l}-11 /+11 \\
-8 /+8 \\
-8 /+7 \\
-6 /+4\end{array}$ & $\begin{array}{l}40.5^{* * *} \\
50.9 \\
64.6 \\
80.1\end{array}$ & $\begin{array}{l}1 \\
4 \\
1 \\
2\end{array}$ & $\begin{array}{r}2 \\
12 \\
2 \\
8\end{array}$ & $\begin{array}{r}6 \\
30 \\
6 \\
20\end{array}$ & $\begin{array}{l}0.70 \text { to } 0.81 \\
0.86 \text { to } 1.02 \\
1.05 \text { to } 1.16 \\
1.30 \text { to } 1.43\end{array}$ & $\begin{array}{l}0.75 \\
0.92 \\
1.10 \\
1.38\end{array}$ & $\begin{array}{l} \pm 0.022 \\
\pm 0.014 \\
\pm 0.024 \\
\pm 0.015\end{array}$ & $\begin{array}{l}-7 /+8 \\
-7 /+11 \\
-4 /+5 \\
-6 /+4\end{array}$ & $\begin{array}{l}43.3^{* 0 * 4 *} \\
53.0 \\
63.5 \\
79.8\end{array}$ \\
\hline
\end{tabular}

$\dagger$ The percentage of control is calculated by taking the average amount of acetylcholine synthesized in the serum of controls as 100 per cent: ${ }^{*} 1.45 ;^{* *} 2.08 ;^{* * *} 1.16 ;^{* * * *} 1.73$.

$\ddagger$ Most seriously ill patient: +++++ ; least seriously ill patient: + . 
Incubated mixtures containing serum collected before and after the administration of $15 \mathrm{mgm}$. neostigmine bromide by mouth to 2 healthy adults, yielded similar acetylcholine content. All patients with myasthenia gravis were taking neostigmine bromide during these experiments. Blood samples were collected both before and after the morning medication. No significant difference between the 2 sets of blood samples was noted as regards acetylcholine synthesis.

\section{Series 2. The effect on acetylcholine synthesis of the mixture of the control serum and the serum from patients with myasthenia gravis}

A mixture of the serum of controls and the serum from patients with myasthenia gravis synthesized at $38^{\circ} \mathrm{C}$. an amount of acetylcholine approximately equivalent to the sum of the synthesis of the 2 sera.

\section{Series 3. Effect of the dialysate of serum on the synthesis of acetylcholine}

To ascertain whether the factors which modify the synthesis of acetylcholine in the frog brain in vitro are dialyzable, serum was dialyzed through a semi-permeable cellophane membrane. Three cc. of serum were placed in a flat glass container ( $4 \mathrm{cc}$. volume), separated from another similar glass container by a cellophane membrane. This second vessel contained $3 \mathrm{cc}$. of Ringer's solution (mammalian type) and the apparatus was shaken for 4 hours at $23^{\circ} \mathrm{C}$. The effect of the dialysate on the acetylcholine synthesis was then compared with the effect of Ringer's solution: $2 \mathrm{cc}$. of dialysate and $2 \mathrm{cc}$. of Ringer's solution were added to mixtures of frog brain. glucose, and physostigmine, incubated, and assayed as described above. The results are summarized in Table VII.

Frog brain mixed with 2 cc. of dialysate obtained from control sera, synthesized $0.68 \mu \mathrm{gm}$. acetylcholine at $38^{\circ} \mathrm{C}$. The amount of acetylcholine synthesized at $38^{\circ} \mathrm{C}$. in mixtures containing frog brain-Ringer's solution averaged 0.41 $\mu \mathrm{gm}$. acetylcholine per $100 \mathrm{mgm}$. of frog brain. An increase of acetylcholine synthesis can best be demonstrated at $38^{\circ} \mathrm{C}$., a temperature at which the difference between synthesis in mixtures of frog brain-Ringer's solution and frog
TABLE VII

Acetylcholine synthesized during 4 hours' incubation in mixtures containing 1. Frog brain and Ringer's solution; 2. Frog brain and dialysate of control serum; and 3. Frog brain and dialysate of serum from patients with myasthenia gravis expressed in $\mu \mathrm{gm}$. per $100 \mathrm{mgm}$. of frog brain (assays of non-boiled mixtures)

\begin{tabular}{|c|c|c|c|c|}
\hline \multirow{2}{*}{$\begin{array}{l}\text { Tem- } \\
\text { perature }\end{array}$} & \multirow{2}{*}{$\begin{array}{l}\text { Mixtures containing frog } \\
\text { brain and }\end{array}$} & \multirow{2}{*}{$\begin{array}{l}\text { No. of } \\
\text { expts. }\end{array}$} & \multicolumn{2}{|c|}{$\begin{array}{l}\text { Amount of acetyl- } \\
\text { choline synthesis }\end{array}$} \\
\hline & & & Mean & S.E. \\
\hline $\begin{array}{l}38^{\circ} \mathrm{C} . \\
38^{\circ} \mathrm{C} .\end{array}$ & $\begin{array}{l}\text { Ringer's solution } \\
\text { Dialysate from controls }\end{array}$ & $\begin{array}{r}22 \\
5\end{array}$ & $\begin{array}{l}0.41 \\
0.68\end{array}$ & $\begin{array}{l} \pm 0.013 \\
\pm 0.049\end{array}$ \\
\hline $\begin{array}{l}23^{\circ} \mathrm{C} \text {. } \\
23^{\circ} \mathrm{C} \text {. }\end{array}$ & $\begin{array}{l}\text { Ringer's solution } \\
\text { Dialysate from } R \text { (my- } \\
\text { asthenia gravis) }\end{array}$ & $\begin{array}{l}9 \\
5\end{array}$ & $\begin{array}{l}0.70 \\
0.55\end{array}$ & $\begin{array}{l} \pm 0.023 \\
\pm 0.038\end{array}$ \\
\hline
\end{tabular}

brain-control sera is greater than at $23^{\circ} \mathrm{C}$. The results indicate that at least some of the potentiator substances in the serum are dialyzable.

To ascertain whether sera from patients with myasthenia gravis contain dialyzable substances that decrease the acetylcholine synthesis, mixtures of frog brain-dialysate of sera from patients with myasthenia gravis and mixtures of frog brain-Ringer's solution were incubated at $23^{\circ} \mathrm{C}$., a temperature favorable for acetylcholine synthesis in mixtures containing frog brain and Ringer's solution and therefore suitable for demonstrating a depression. The amount of acetylcholine synthesized in mixtures containing frog brain-Ringer's solution averaged $0.70 \mu \mathrm{gm}$. acetylcholine. Mixtures containing frog brain and $2 \mathrm{cc}$. dialysate obtained from the serum of patient $\mathrm{R}$ with myasthenia gravis synthesized, on the average, $0.55 \mu \mathrm{gm}$. acetylcholine. The results suggest that at least some of the substances responsible for the decrease of the acetylcholine synthesis in patients with myasthenia gravis are dialyzable. Although it appears that there is contained in the serum of patients with myasthenia gravis an agent that inhibits acetylcholine synthesis, it may not be inferred that such agent is absent in the control sera.

\section{DISCUSSION}

These data reveal that the serum from patients with myasthenia gravis is an unfavorable medium for the synthesis of acetylcholine. The acetylcholine synthesis in mixtures of frog brainRinger's solution-control serum is almost 3 times as great as in mixtures of frog brain-Ringer's 
solution-serum from a patient seriously incapacitated by myasthenia gravis (12).

This difference is significant, since variation from subject to subject, both among the healthy and among those with diseases other than myasthenia gravis, was less than \pm 15 per cent, and it was usually under \pm 10 per cent. The difference in acetylcholine synthesis between samples of serum of different patients with myasthenia gravis was considerable, but the variation in the sample of serum of any one myasthenic patient was less than \pm 15 per cent. The serum from patient $\mathrm{H}$ with severe myasthenia gravis was examined over a long period during which the clinical state changed slightly. This may have a bearing on the wider variation $(-20,+15$ per cent from the average) observed in this patient. Hence, the usually more than 100 per cent greater synthesis of acetylcholine with control serum, as compared with the serum from patients seriously incapacitated by myasthenia gravis, represents a major difference in the nature of the serum samples. ${ }^{7}$

Moreover, this reduction of acetylcholine synthesis is not an expression of debility, cachexia, immobility, or prostration.

It is of interest that the magnitude of the decrease in acetylcholine synthesis is related to the severity of the myasthenia gravis in this small group of patients. The serum from patients with the more serious clinical disability supported acetylcholine synthesis less well than did serum of patients in a better clinical state. With the method now employed, the determinable reduction in the less seriously ill is so small that obviously this technic is not of value for diagnostic purposes.

7 The spinal fluid from patients with myasthenia gravis exerts a similar effect on the synthesis of acetylcholine to that of the serum (13).

While this paper was in press, Stoerk and Morpeth (14), using rat brain as a source of enzyme, reported that they could detect no difference in the amounts of acetylcholine synthesized in the presence of serum from control subjects and serum from patients with myasthenia gravis. Since they were also unable to demonstrate any difference in the amounts of acetylcholine synthesized in the presence of control serum as compared to Locke's solution, it is inferred that their adaptation of the method of Quastel, Tennenbaum, and Wheatley was not adequate for the demonstration of such differences in the synthesis of acetylcholine as are relevant to this discussion.
Since the dialysate of serum affects acetylcholine synthesis, it may be inferred that some of the modifying agents, both potentiators and depressors, are of a relatively small molecular size and not colloidal in nature.

Since acetylcholine synthesis is greater in frog brain-Ringer's solution-control serum mixtures than in frog brain-Ringer's solution mixtures, it is likely that the serum furnishes additional substrate to the enzyme responsible for acetylcholine synthesis. Also, a temperature of $38^{\circ} \mathrm{C}$., that interferes with acetylcholine synthesis in frog brain-Ringer's solution mixtures, permits, in frog brain-Ringer's solution-serum mixtures, more synthesis than is found at $23^{\circ} \mathrm{C}$. Apparently at $38^{\circ} \mathrm{C}$., this particular enzyme is more active than at $23^{\circ} \mathrm{C}$., and though the substrate contributed by frog brain is converted at $38^{\circ} \mathrm{C}$. into a state less suitable for acetylcholine synthesis, the substrate added by the serum compensates for the loss.

The decrease in acetylcholine synthesis demonstrated in these in vitro studies suggests that there may be similar defects in acetylcholine synthesis in patients with myasthenia gravis. There is reason to assume that the serum of patients with myasthenia gravis which poorly supports acetylcholine synthesis in vitro acts similarly in vivo.

It seems probable that in patients with myasthenia gravis, the acetylcholine available at the synapses eventually becomes insufficient for effective and repeated contraction of the muscle. Neostigmine aids these patients by impeding the breakdown of the diminished quantities of acetylcholine.

\section{SUMMARY}

1. Using frog brain-serum and frog brainRinger's solution mixtures as preparations for studying rate of acetylcholine synthesis, and the sensitized rectus abdominis muscle of frog for bioassay of acetylcholine content of the mixtures, the effect of control sera and sera from patients with myasthenia gravis on acetylcholine synthesis was investigated.

2. In frog brain-Ringer's solution mixtures, acetylcholine synthesis is greater at $23^{\circ} \mathrm{C}$. than at $38^{\circ} \mathrm{C}$., while the reverse is true of frog brainserum mixtures. 
3. Acetylcholine synthesis in frog brain-control serum mixtures or in frog brain-dialysate of control serum mixtures exceeded that from frog brain-Ringer's solution mixtures.

4. Acetylcholine synthesis in mixtures of frog brain and serum from patients with myasthenia gravis was significantly less than that in frog brain-control serum mixtures. The more severe the myasthenia gravis, the less the acetylcholine synthesis. In mixtures of frog brain and dialysate of serum from patients with myasthenia gravis, acetylcholine synthesis was less than in mixtures of frog brain-Ringer's solution.

5. These results suggest that there is a defect in acetylcholine synthesis in patients with myasthenia gravis which can explain the fatiguability and weakness of these patients.

\section{BIBLIOGRAPHY}

1. Walker, M. B., Case showing effect of prostigmin on myasthenia gravis. Proc. Roy. Soc. Med., 1935, 28, 759.

2. Milhorat, A. T., The choline-esterase activity of the blood serum in disease. J. Clin. Invest., 1938, 17, 649.

3. Lanari, A., "Myastenia gravis" y transmisíon química neuro-humoral. Rev. Soc. argent. de biol., 1937, 13, 239.

4. Harvey, A. M., and Masland, R. L., The electromyogram in myasthenia gravis. Bull. Johns Hopkins Hosp., 1941, 69, 1 .
5. Harvey, A. M., and Lilienthal, J. L., Jr., Observations on the nature of myasthenia gravis. Ibid., 1941, $69,566$.

6. Harvey, A. M., Lilienthal, J. L., Jr., and Talbot, S. A., Observations on the nature of myasthenia gravis. The effect of thymectomy on neuromuscular transmission. J. Clin. Invest., 1942, 21, 579.

7. Quastel, J. H., Tennenbaum, M., and Wheatley, A. H. M., Choline ester formation in, and choline esterase activities of, tissues in vitro. Biochem. J., 1936, 30, 1668.

8. Riesser, O., Über die durch Azetylcholin bewirkte Erregungskontraktur des Froschmuskels und ihre antagonistische Beeinflussung durch Atropin, Novokain und Kurare. Arch. f. exper. Path. u. Pharmakol., 1921, $91,342$.

9. Chang, H. C., and Gaddum, J. H., Choline esters in tissue extracts. J. Physiol., 1933, 79, 255.

10. Corteggiani, E., Gautrelet, J., Kaswin, A., and Mentzer, C., Sur l'existence d'un complexe libérant l'acétylcholine dans les centres nerveux sous l'influence de la chaleur. Compt. rend. soc. de biol., 1936, 123, 667.

11. Loewi, O., and Hellauer, H., Vergleich der Acetylcholinausbeute aus dem Zentralnervensystem des Frosches bei Extraktion mit $\mathrm{HCl}$-Alkohol und Trichloressigsäure sowie mittelst Kochen. Arch. f. d. ges. Physiol., 1938, 240, 449.

12. Torda, C., and Wolff, H. G., The nature of myasthenia gravis. Science, 1943, 98, 224.

13. Torda, C., and Wolff, H. G., Effect of spinal fluid from patients with myasthenia gravis on the synthesis of acetylcholine in vitro. Science, 1944, in press.

14. Stoerk, H. C., and Morpeth, E., The nature of myasthenia gravis. Science, 1944, 99, 496. 